\title{
Religion and Black Racial Identity in Du Bois's Sociology
}

\author{
Sandro Segre ${ }^{1,2}$ (D) \\ Accepted: 6 April 2021 / Published online: 6 May 2021 \\ (c) The Author(s) 2021
}

\begin{abstract}
This article focuses on W.E.B. Du Bois's ambivalent reception of Protestantism, and of religion in general. It argues that he rejected institutional Protestantism as characterized by cold formalism, but thought that the teaching and practices of this religion as taking place the Negro Churches were still relevant to most American Blacks. As pointed out by some secondary literature, Du Bois maintained that religious institutions gave comfort, social cohesion and a collective identity of their own to Blacks, who were an oppressed minority; however, only the Blacks' racial consciousness could improve their social and political position. Institutional religion was then an important identity source for Blacks in general. It was not, however, for Du Bois himself. Du Bois had experienced racial discrimination and abuse based on the color line, and had therefore formed his social identity as a member of the Black race in the United States. This identity was the most salient to him and elicited his greatest commitment.
\end{abstract}

Keywords Identity salience $\cdot$ Identity commitment

\section{Introductory Remarks}

W.E.B. Du Bois devoted his whole professional life to the study of his own race in order to advance its freedom and dignity (Appiah, 2007, p. xix). Throughout his whole adult life, from his early teaching experience in the racially segregated South to his last years as an expatriate in Ghana, he labeled himself as a Black American, for this was his social identity. How this identity coexisted with his Protestantism is the subject matter of this article. Concerning Du Bois's attitude to religion, the secondary literature has underlined its "enormous significance" in conjunction with his emphasis on its consequences, whether they be good or bad (cf. Zuckerman, 2000a, b, pp. 5-8). Du Bois's ambivalent evaluation of religion is related to its potential

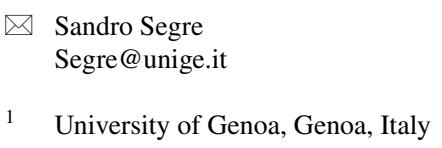


-rather than actual- contribution to the attainment of his ultimate goals; namely, "to undo the color line and advance the cause of the oppressed" (Itzigsohn \& Brown, 2020 , p. 106). His profound interest in religion notwithstanding, Du Bois was never a devout follower of his own Protestantism, whose ethical attitudes he rejected (cf. Du Bois, 1903, p. 236), or of any other religion.

This was so in spite of his early exposure to the Methodists and Baptist denominations (cf. Du Bois, 1903, p. 84). As he stated in his Autobiography (Du Bois 1968, but originally published in 1960), since his young years he had a scientific rather than a religious mind (p. 205). He accordingly "turned further from religious dogma", though he was "still a 'believer' in orthodox religion" as represented in his case by the Congregational church. The church was in his high-school years his "chief communication with the people of the town" outside of school. Later, while he was a student in Germany (1892-1894) he became a freethinker (Du Bois 1968, pp. 88, 285). In his last years he embraced Marxism and atheism while dismissing religion as a source of oppression (cf. Du Bois 1968, pp. 41-42, 400). Du Bois remained thus uncommitted to any particular faith for the better part of his life. Still, the "Negro problem" continued to be his main personal and scholarly concern, as his own life illuminated the concept of race (Aptheker, 1968, p, 5). However, toward its end "Du Bois saw the American Negro as a metaphor for class relations within the wider social order" (Bobo, 2007, p. xvi). Thus, Du Bois remained a believer in some faith during his whole life; his faith was religious, though never orthodox, until his last years when it became entirely secular.

This article sets out to reassess his writings on religion. It focuses first on Du Bois's two counterposed views of religion; the former considers religion a set of moral principles having a divine origin, and the latter a set of institutions which still call themselves Christian but fail to abide by these principles. This article then briefly takes into consideration some secondary literature that deals with Du Bois's sociology of religion and focuses on some divergent interpretations of it. It will be shown how discussing this subject -Du Bois's sociology of religion- will be conducive to tackling his central theme, which concerns the consequences of racial discrimination (the color line) for Blacks in general, and particularly for Du Bois himself.

\section{Du Bois's Sociology of Religion in the Context of his Whole Work}

The sociology of religion of W.E.B. Du Bois is part of his sociological work on the condition and predicament of the Black race. Du Bois's paramount purpose was here, as in general, "the ultimate abolition of the color line" (Du Bois, 1935, p. 297). This end could be attained, in his judgment, "through a study of the conditions and problems" of Du Bois's own group of his fellow Blacks ((Du Bois, 1935, p. 206). As this group was a target of "human hatred" (Du Bois, 1920, p. xiv), Du Bois wished to make it the object of a scientific social study with the aim not only "to make the Truth clear", but also "to represent it in such as shape as will encourage and help social reform" (Du Bois, 1920, p. 33). Social reform would be indeed necessary 
as "today poverty, sickness and crime are choking the path" of Black advancement (Du Bois, 1940, p. 109), and residential segregation, which has been in most cases enforced "by outer pressure," compels Blacks to "live among themselves ... in the least pleasant dwelling places" (Du Bois, 1940, p. 92).

Sharing the same religious faith in no way bridged the residential, social and economic distance between Blacks and Whites; for there was between the two races, despite their daily contacts, "almost no community of intellectual life or points of transference" (Du Bois, 1903, p. 210). As he made this same point in his The Philadelphia Negro (first published in 1899), "the great middle class of white people seldom, if ever," were "brought into contact with Negroes" (Du Bois, 2007, p. 78). Segregation by color was present even between members of the privileged classes (Du Bois, 1903, p. 192). Blacks that belonged to the learned professions were not distinguished from the less privileged Blacks by their church attendance, as "Practically all Negroes go to their own churches, where they have, save in a very few cases, clergymen of their own races" (Du Bois, 1899, p. 79). Despite the presence of racial prejudice even within Black communities (cf. Du Bois, 1899, p. 240), religious rituals provided Blacks of different stations in life with a common racial consciousness and identity; that is, with ways of how they defined themselves, and how these definitions have been shaped in the course and by virtue of social interactions (cf. Charon, 2001, pp. 86-88, 164-165).

Notwithstanding the Blacks' common identity and "the decreasing influence of the Negro church" affecting the whole Black community, Du Bois called attention to class differences in their religious lives such as "the distinctly Quaker characteristics" of "the better class families." Even there, however, "there is easily detected a tendency to let the communal church and society life trespass upon the home." Among such characteristics, Du Bois emphasized in addition to "the proverbial good nature and candor" (Du Bois, 1899, p. 41) the "perfect sincerity" in their efforts to increase church membership, and described them as "hearty and easy-going people," always ready to "welcome all comers and ask few questions" (Du Bois, 1899, pp. 136, 145). Thus, Du Bois laid emphasis on the shared features connoting the religion, social life and self-definition of Black Americans, rather than their inner distinctions along class lines. The Blacks' shared identity had made it possible, according to Du Bois, to explain from their vantage point the experiences not only of segregation, but also of the humiliations and mistreatments which they have received from the dominant race (Du Bois, 1899, p.136). As for Du Bois himself, race provided not only the source of his person identity, in the sense of self-definition as formulated by identity theory (cf. Charon, 2001, p. 86), over all his adult life. It also provided his most salient identity.

For race was the most likely and most frequently invoked by him as his own identity, to the effect that race was also the identity to which he was most committed; and that his skin color was conducive to holding social positions and performing associated roles that would have been otherwise precluded to him (cf. Stryker, 1980, pp. 57-59). Further, race provided Du Bois with a social identity, namely, with a social group with which he could identify as a bona fide member (cf. Burke \& Stets, 2009, pp. 118-121). The Whites with whom Du Bois interacted were of various sorts, such as fellow sociologists, academic authorities, Government officials or editors of 
scholarly journals. His social position and roles depended upon stable expectations on the part of some particular Whites of how Blacks should "properly" deport themselves. Social expectations concerning Blacks were especially prominent among the White folks inhabiting the racist South. Du Bois was wary of them because of their potential or actual violence against his race (cf. Du Bois 1968, p. 222. These folks were, possibly more than others, responsible for establishing and upholding the color line, viz., the virtually complete absence of "intellectual commerce" (Du Bois, 1903, p. 211) between the two races, the frequency of their social interactions notwithstanding.

The absence of social relations between these two ethnic groups makes it difficult to assess Du Bois's knowledge of White religiosity, of which he had quite limited direct experience. His interest in it was chiefly, if not exclusively, as a comparison object to Black religiosity. The sociological study of religion was for Du Bois instrumental to reach a plurality of aims that will be presently indicated. All these aims were related to his central theme, namely, investigating the consequences of the color line for his racial group and for himself. They were as follows. First, Du Bois set out to bring into light the significance of Blacks' religiosity to the formation of their racial consciousness. Second, by means of his distinction between the African American and the White religiosity Du Bois sought to convey the image of an unabridged and unbridgeable distance between these two racial groups (the color line), only the former being capable of having genuine religious experiences; whereas the latter, with reference to the White Christian church, was the object of derogatory descriptions such as "appealing to primitive passions and emotions" (Du Bois, 1915, p. 141) and blamed for having "accepted the program of caste for Negroes" (Du Bois, 1931, p. 176).

Finally, by describing the discriminatory and occasionally violent practices Whites enacted against Blacks even within the fold of their common religious faith Du Bois pointed not only to his own life experience, but also to his social identity as a member of the Black race in the United States. This identity was the most salient to him and elicited his greatest commitment. His late embrace of Soviet Marxism made no fundamental change in either his identity as a member of the Black race, or in his fundamental religious concerns. His identity and thought displayed continuity rather than evolution. As a Du Bois student has put it, "By the end of his life ... Du Bois rejected the hallmarks of American religious culture ... and instead characterized Communism as the social realization of Christian teachings" (Blum, 2007, p. 8). Embracing Marxism was then the manifestation of the same character trait which, in Du Bois's own words, was also manifest "in the older African wails and chants, the distinctively African American folk song set to religious words and Calvinistic Symbolism" (Du Bois, 1913).

As Lawrence Bobo, another eminent Du Bois scholar, has written, his was "an early voice identifying the powerful role of the church in black social life and community affairs" (Bobo, 2007, p. xxxviii). This was a role which Du Bois himself as a self-conscious African American fully endorsed. His racial identity and painful awareness of discrimination made him alert, after visiting the destroyed Warsaw ghetto, to the unfair treatment inflicted to other minorities such as the Jews. He wrote in this connection that his view of the Warsaw ghetto provided him with "not 
so much clear understanding of the Jewish problem in the world as it was a real and more complete understanding of the Negro problem" (Du Bois, 1952, p. 199).

\section{Black Religiosity and the Negro Church}

Du Bois attempted several times to convey his conception of religion by narrating a fictional story of Jesus Christ's coming to the racist South, and his quite different reception on the part of the Blacks and Whites living there. Jesus was portrayed as a dark preacher, a divine figure, and the very embodiment of morality based on mutual aid, love, and respect (cf. Du Bois, 1920, pp. li-lx). Even though Du Bois imputed to the Black churches other functions such as the promotion of general intelligence and striving for social betterment, "The chief function" of the Black churches in morals -he wrote- was "the setting of moral standards for the people" on the part of the congregations, and in particular, "to conserve old standards and create about them a public opinion which should deter the offender" (Du Bois, 1899, pp. 144, 147). Considering the importance Du Bois imputed to having qualified religious leaders in the Negro Church, the scarcity of such leaders and the great number of inadequately trained and morally tainted clergymen was to him a cause of concern (cf. Du Bois 1912). Du Bois's embracing of socialism in the last decades of his life (cf. Du Bois, 1968, pp. 400-401; 2007, p. 160) led him to emphasize work as an additional component of morality.

As he wrote, "I have realized that Love is God and Work is His prophet" (Du Bois, 2007, p. 162). Du Bois aspired to a world that would accept and enact this morality, and would therefore discard racism. In his own words, "Only faith in humanity will lead the world to rise above the present color prejudice" (Du Bois, 1920, p. xxxi). Du Bois found expression of this ideal world, insofar as the United States was concerned, in the religiosity of in the Black people who were "despised and rejected" as Jesus had been (Du Bois, 1920, p. lix). He viewed its frenzied character and "spiritual emotionalism" (Du Bois, 1924, p. 165) as "the one true expression of a people's sorrow, despair, and hope" (Du Bois, 1903, p. 220). As Du Bois maintained elsewhere, "to most of the four million Black folk emancipated by the civil War, God was real. They knew him. They had met him personally in many a wild orgy of religious frenzy, or in the black stillness of the night" (Du Bois, 1935, p. 111). In his own time, however, he felt that the ideals and the very character of the Black people as embodied by the Preacher and the Teacher to some extent belonged to a bygone era; for even among Blacks, as among the White folks, "a question of cash and a lust for gold" was prominent (Du Bois, 1903. pp. 98-99).

When Du Bois stated that "No American now believes in his religion", he referred to White Americans only, for he added that religion was still relevant to most Blacks. He observed in this regard that "Practically every American Negro is a church member" (Du Bois, 1903, p. 225), and added in a different context that "The essence of a study of religion in the South is a study of the ethics of slavery and emancipation" (Du Bois, 1907, p. 69). As Du Bois maintained, religiosity rather than formal religious participation had declined. This religious 
feeling found expression, "up to the time of the emancipation" (1863), in a variety of ways, "from the silent rapt countenance or the low murmur and moan to the mad abandon of physical fervor" (Du Bois, 1903, p. 220). Secularization was accordingly for Du Bois chiefly a social process relevant to Whites rather than to Blacks. The former ethnic group needed the latter to revive its own religiosity.

As Du Bois asserted, "the cold formalism of [White] upper class England and New England needed the wilder spiritual emotionalism of the Black man to weld out of both to weld out of both a rational human religion based on kindliness and social uplift" (Du Bois, 1924, pp. 165-166). Also, he praised the Blacks for their "sense of meekness and humility" (Du Bois, 1924, p. 168). The White church, however, would hardly have consented to join forces with its Black counterpart as it has opposed "every great modern social reform" and in particular "the emancipation of the Negro slave" (Du Bois, 1952, p. 170). In this secularized age American Blacks' religiosity was still strong in most cases, even though -as he wrote with reference to Blacks- "the young people are leaving the church" (Du Bois, 1952, p. 24). From his viewpoint, those Blacks who were still devout were in fact the true heirs to Jesus' teaching; as "it was Black Americans who actually lived more Christian lives" (Zuckerman, 2000b) in accordance with "the deep religious feeling of the real Negro heart" (Du Bois, 1952, p. 236).

The Negro church was, in Du Bois's judgment, "the first distinctively Negro American social institution." It was also "the sole surviving social institution of the African fatherland" (Du Bois, 1952, p. 164). The African American church and more in general the Blacks' religious life provided the focus of his sociology of religion (cf. Zuckerman, 2002, p. 243). However, in the American South on which he focused his attention ${ }^{1}$ religion has become secularized, and the specifically Black emotional character has faded away. While bigoted, it has often omitted -insofar as both Blacks and Whites are concerned - to pay allegiance to several divine commandments (cf. Du Bois, 1903a, pp. 202-203). Du Bois was persuaded that the White church had been "a miserable failure". White Christianity has been "daily stamping hypocrisy upon" Blacks' religion and land (Du Bois, 1907, p. 86); as with few exceptions the White folks had swerved from practicing "with even reasonable approximation the democracy and unselfishness of Jesus Christ" (Du Bois, 1920, p. xv; cf. also Moore, 1981, pp. 103-104; Zuckerman, 2002, pp. 246-247).

By contrast, the secularized Negro church had preserved some features of its own that have prevented it from experiencing complete failure. For it had become "the social center of Negro life in the United States, and the most characteristic expression of Negro character" (Du Bois, 1903a, pp. 221-222). The Negro being "a religious creature" (Du Bois, 1899, p. 143) and part of "a proscribed people", he or she must have "a social center", which is "for this people the Negro church" (Du Bois, 1903a, p. 225). It must have, in other words, a "realization of a racial

\footnotetext{
1 Du Bois's focus being on religion in the South, he only briefly mentioned Black religion in the North of the United States. He pointed in this connection to the different attitude of its members in comparison to those living in the South: "Groups of cold, fashionable devotees, in no way distinguishable from similar white groups save in the color of the skin." The Northern churches were unsympathetically described as "large social and business institutions" that provided information and amusement to their members while shunning unpleasant questions (cf. Du Bois, 1903a, pp. 233-236).
} 
self-consciousness" (Evans, 2007, p. 293). Du Bois's description of the function of the Black church was both descriptive and normative (cf. Evans, 2007, p. 275). As "the hub of Black communities" (Itzigsohn \& Brown, 2020, p. 40) and "a center of their social life and intercourse," to "a degree unknown to white churches even in the country" (Du Bois, 1899, pp. 143, 145), the Negro church had achieved what the White church had not, for it had inspired humanity into the formalism of the White church. By virtue of its creed and music had provided expression to its members' "extraordinary growth and vitality" (Du Bois, 1915, as quoted by Morris, 2015, p. 121; cf. also Du Bois, 1952, pp. 165-166, and Moore, 1981, p. 113).

By contrast, the White world is not linked, spiritually and emotionally, "to the Christianity of the Gospels" (Du Bois, 1960, p. 79). Its religious practices reflected the shallowness of its faith, which had become a matter of social expediency rather than inner persuasion, and which was but a component of most White Americans' conservative and racist worldview (Du Bois, 1960, pp. 78-85). The Gospels did not teach to discriminate people because of their skin color, or on any other ground. Discrimination in educational, economic and social opportunities as experienced by Blacks living in an American city was "a disgrace to its Christianity, to its spirit of justice" (Du Bois, 1899, p. 274). Nonetheless, in the American South "a determined psychology of caste was built up. In every possible way it was impressed and advertised that the White was superior and the Negro an inferior race" (Du Bois, 1935, p. 621); that, in other words, a Negro like Du Bois himself "was and must be a thing apart" (Du Bois, 1940, p. 69). Whites enforced segregation in virtually all the aspects of the Blacks' lives such as their social and economic situation, residence, and religion (Du Bois, 1960, pp. 92-93; 2019, pp. 192-193).

\section{The Blacks' Emotional and Spiritual Expression of Religion as the Central Theme of Du Bois's Sociology}

In his Autobiography Du Bois recalled an episode when as a young man he approached a church in the course of a religious ceremony. As he reminiscenced, he was struck by "the air of intense excitement that possessed the mass of Black folk" (Du Bois, 1968, p. 120). Du Bois had already noticed in his younger years what he called "the frenzy of shouting" that -in conjunction with other sensorial expressions of religious fervor- connoted Black religious life before the time of Emancipation. Blacks believed that shouting, weeping, laughing, having visions, and experiencing trance were "visible manifestations of the God" that were necessary to "a true communion with the invisible" (Du Bois, 1903, p. 220). Subsequently, as he maintained, these frenzied manifestations of Black faith gradually gave way to the institutional Black churches with which he was familiar, and about which he had ambivalent feelings.

As "a poor and oppressed minority" (Du Bois, 1903, p. 235), they are "an unhappy people" whose "Sorrow Songs" at the times of slavery told of "death and suffering and unvoiced longing" toward a better world (Du Bois, 1903, p. 288). These are the slave songs expressing "the single spiritual heritage of the nation and the greatest gift of the Negro people" world (Du Bois, 1903, p. 286), but also "the 
shadow of fear" of a helpless and homeless people (Du Bois, 1903, p. 294). By means of this "primitive African music" (Du Bois, 1903, p. 289) "the slave spoke to the world" (Du Bois, 1903, p. 292). Later, however, Afro-American music lost its original hallmark and took on both Black and White characters. "Debasement and imitations" (Du Bois, 1903, p. 291) have followed consequently. Apparently, then, Du Bois found in these Sorrow Songs not only the pristine and uncorrupted expression of the African-American people, but of his own identity as well as a Black man that partook of "Black human nature" (Du Bois, 2012, p. 59); an identity, as he maintained, radically different from that of the White folk.

\section{Du Bois on Religion: A Variety of Views}

The main contents of the reception of Du Bois's sociology of religion may be summarized as follows:

1) The religiosity of the Black people embodies morality since it is most faithful to the teaching of Jesus Christ insofar as its beliefs and practices are concerned.

2) By contrast, the White people's religiosity has been a failure as it has departed from the Gospels.

3) This departure, which has been spiritual and emotional, has found expression in the shallowness of the Whites' religious practices.

4) The secularization process has affected Blacks and Whites differently in that it has promoted an active segregated social life within the Black communities, on the one hand; on the other hand, it has contributed to the decline and virtual disappearance of religiosity, and even of religion, in the Whites' group.

These four points will be discussed here following this order. It should be first remarked, however, that not all the introductions to Du Bois's sociology deal in one way or another with his sociology of religion, though none of them belittles its relevance. Some of them, such as Taylor's (2010), do not have a sociological character at all and possibly for this reason do not discuss this particular aspect of his varied thought, A few of them just mention this aspect but pay no particular attention to it. Thus, Charles Lemert's introduction (2005) keeps a steady focus on Du Bois's Black Reconstruction in America. This is a historical work where religion does not constitute a prominent theme. Other introductions deal more broadly with his whole work, the sociology of religion being merely a component which is sometimes just mentioned, but that is not delved into (cf. Itzigsohn \& Brown, 2020, p. 40). Morris's recent and authoritative introduction to Du Bois's life and work presents his methodology and epistemological orientation, but only hints at his sociology of religion (cf. Morris, 2015, p. 121).

Green and Wortham (2018) have laid emphasis on Du Bois's triangular methodology, to the effect that he made use of a plurality of methods in his empirical research. Even though Du Bois's sociology of religion has received no particular attention here, investigations conducted in this field of studies also point to the 
"impressive ... array of traditional research methods" he successfully employed, as Zuckerman has pointed out (Zuckerman, 2002, p. 242). Zuckerman himself has provided an instance of those few scholars who have paid particular attention to Du Bois's contribution to the sociology of religion. We shall then turn to those few instances of the secondary literature that focus upon this contribution with the purpose of assessing their interpretation of Du Bois's writings in this field of studies. Zuckerman has focused on the following themes: first, Du Bois's treatment of White and Black Christianity; second, religious organizations as social centers; and finally, his religious identity. The present discussion will follow this same order (cf., in this particular regard, Zuckerman 2000a, 2000b, 2002, 2004).

While the first two subjects provide information on important items of Du Bois's sociology of religion, as should be the case of any introduction to his work, the section discussing his religious identity covers new ground and deserves particular attention. As Zuckerman has argued, Du Bois's religious identity was of the greatest relevance to him as "a source of personal and professional inspiration." In his earlier work, as a devout Christian he wrote prayers for his own use. Their content "overflows with spiritual expression and reverence." Subsequently, however, his faith "gave way to skepticism and agnosticism" (Zuckerman, 2002, pp. 5-6). Zuckerman makes here reference to Du Bois's, 1960 autobiography, which gives clear indication of his late gradual detachment from religion: "From my $30^{\text {th }}$ year on" -that is, approximately at the turn of the nineteenth century- "I have increasingly regarded the church as an institution which defended such evils as slavery, color caste, exploitation of labor and war" (Du Bois, 1960, p. 285).

Notwithstanding Du Bois's progressive withdrawal from institutional religion until he became a self-professed atheist, Zuckerman observes that he never really became such a person. Du Bois's profound interest in religion at any time of his scholarly life was not the immediate consequence of personal involvement in it, which decreased in the course of his life. Rather, religious institutions such as the Black church were an "immediate, everyday, this-worldly sources of communal comfort in the face of everyday oppression" (Zuckerman, 2002, p. 250). Differently than Zuckerman, Evans (2007) has argued that Du Bois's "unstated assumption" was that Blacks' ideals and goals could come to fruition only as long as a racial selfconsciousness would be realized. Attaining this goal in turn required that a united Negro Church be created in order "to confront the common problems of the Blacks," such as social reform and political empowerment" (Evans, 2007, p. 293). These different interpretations of Du Bois's sociology of religion will be related to his main contents.

Zuckerman's stress on Du Bois's interest in and initial personal involvement with organized religion, and subsequent detachment from it, is consistent with Du Bois's writings. Zuckerman's contribution lies in his attention to the changes which Du Bois underwent in his religious identity, and in his functional interpretation of Du Bois's sociological writings on religion as a source of social cohesion and collective identity. Evans's insistence on the Blacks' racial consciousness as a precondition to improving their social and political position is likewise in agreement with Du Bois's writings and major concerns as well. Both authors have dwelt on the importance which the spiritual and emotional expression of religious faith 
held, according to Du Bois, to bind together most members of the Black communities. This point of convergence between these two commentators of Du Bois paves the way to a reappraisal of their contribution to the study of Du Bois's sociology in general.

\section{Summary and Conclusion}

This article has aimed to individuate the central themes of Du Bois's sociological work, and has accordingly laid stress on the continuity of his thought rather than on his change. To this end it has focused on his sociology of religion, and especially on his sociological interpretation of Blacks' religious rituals. In keeping with Du Bois, it has been argued here, these rituals gave expression to their collective identity as an oppressed and suffering people, thus promoting their collective consciousness as belonging to the Black race. Du Bois contrasted the significance for Blacks of these rituals and of religion in general to the shallow and inconsequential experience of religion for Whites, which he labeled as "cold formalism" (Du Bois, 1924, p. 165). Religion was then a major source of Blacks' racial identity. This identity was, according to Du Bois, most salient to Blacks and one to which they were most committed. Race was also the source of Du Bois's own social identity.

The set of meanings he attached to his race was not directly related to religious rituals with which he had been involved, for the mature Du Bois had relinquished his original Protestant faith. This set of meanings was rather related to his personal experience as a Black man who spent a considerable part of his life suffering race discrimination. Religion, however, was significant to him indirectly, as a source of Blacks' collective identity and, therefore, of the social group with which he himself identified completely. To the extent that this interpretation is correct, discrimination based on the color line plagued Du Bois himself since it plagued Blacks who formed his own reference group. Du Bois's sociology of religion provided an important key to understand and explain this central theme, for he viewed religious rituals as the past and to an extent still present source of the Blacks' and of his own racial consciousness, and on this ground a most relevant object of sociological investigation.

\section{Declarations}

Conflict of Interest On behalf of all authors, the corresponding author states that there is no conflict of interest.

Open Access This article is licensed under a Creative Commons Attribution 4.0 International License, which permits use, sharing, adaptation, distribution and reproduction in any medium or format, as long as you give appropriate credit to the original author(s) and the source, provide a link to the Creative Commons licence, and indicate if changes were made. The images or other third party material in this article are included in the article's Creative Commons licence, unless indicated otherwise in a credit line to the material. If material is not included in the article's Creative Commons licence and your intended use is not permitted by statutory regulation or exceeds the permitted use, you will need to obtain permission directly from the copyright holder. To view a copy of this licence, visit http://creativecommons.org/licen ses/by/4.0/. 


\section{References}

Appiah, K. A. (2007). The black letters on the sign. W.E.B. Du Bois and the Canon. In W. E. B. Du Bois (1940), Dusk of Dawn (pp. xi-xxiv). Oxford University Press.

Aptheker, H. (1968). Editor's preface. In W.E.B. Du Bois, The Autobiography of W.E.B Du Bois (pp. 5-6). International Publishers Co.

Blum, E. J. (2007). W.E.B. Du Bois American Prophet. University of Pennsylvania Press.

Bobo, L. (2007). Introduction: The black letters on the sign. In W. E. B. Du Bois (1899). The Philadelphia Negro (pp. xxv-Xxx). Oxford University Press.

Burke, P. J., \& Stets, J. E. (2009). Identity Theory. Oxford University Press.

Charon, J. M. (2001). Symbolic Interactionism. An Introduction, an Interpretation, an Integration. Prentice Hall.

Du Bois, W. E. B. (1899). The Philadelphia Negro. Oxford University Press, 2007.

Du Bois, W. E. B. (1903a). The Souls of Black Folk. Gildan Media, 2019.

Du Bois, W. E. B. (1903b). The Negro Church. In P. Zuckerman (Ed.), Du Bois on Religion (pp. 69-89), Altamira Press, 2000.

Du Bois, W. E. B. (1907). Religion in the South. In W. E. B. Du Bois (Ed.), Du Bois on Religion (pp. 69-89). Altamira Press, 2000.

Du Bois W. E. B. (1912). The negro church. In W. E. B. Du Bois (Ed.), Du Bois on Religion (pp. 45-46). Altamira Press, 2000.

Du Bois, W. E. B. (1913). The negro in literature and art. In R. A. Wortham (Ed.), W.E.B. Du Bois and the Sociology of the Black Church and Religion (pp. 109-113). Lexington Books.

Du Bois, W. E. B. (1915). The Negro. Henry Holt.

Du Bois, W. E. B. (1920). Darkwater. Voices from Within the Veil. Brace and Howe.

Du Bois W. E. B. (1924). The Gift of the Spirit. In W. E. B. Du Bois, Du Bois on Religion (pp. 161-168). Altamira Press, 2000.

Du Bois, W. E. B. (1931). Will the Church remove the Color Line?. In W. E. B. Du Bois, Du Bois on Religion (pp 173-179). Altamira Press.

Du Bois, W. E. B. (1935). Black Reconstruction in America. Henry Holt, 2012.

Du Bois, W. E. B. (1940). Dusk of Dawn. Oxford University Press, 2007.

Du Bois, W. E. B. (1952). The Negro and the Warsaw Ghetto. In P. Zuckerman (Ed.), Du Bois on Religion (pp. 197-201). Altamira Press, 2000.

Du Bois, W. E. B. (1960). The Autobiography of W.E.B. Du Bois. H. Apteker ed. International Publishers Co., 1968.

Evans, C. (2007). W.E.B. Du Bois: Interpreting Religion and the problem of the Negro Church. Journal of the American Academy of Religion, 75(2), 268-297. https://doi.org/10.1093/jaarel/lfm001.

Green, D. S., \& Wortham, R. A. (2018). The sociological insight of W.E.B. Du Bois. Sociological Inquiry, 88(1), 56-78. https://doi.org/10.1111/soin.12179.

Itzigsohn, J., \& Brown, K. L. (2020). The Sociology of W.E.B. Du Bois. Racialized Modernity and the Global Color Line. New York University Press.

Lemert, C. (2005). Du Bois, William Edward Burghart (W.E.B.). In G. Ritzer (Ed.), Encyclopedia of Social Theory (pp. 213-218). Sage.

Moore, J. B. (1981). W.E.B. Du Bois. Twayne Publishers.

Morris, A. D. (2015). The Scholar Denied. University of California Press.

Stryker, S. (1980). Symbolic Interactionism. The Benjamin Cummings Publishing Company.

Taylor, P. C. (2010). W.E.B. Du Bois. Philosophy Compass, 5(11), 904-915. https://doi.org/10.1111/j. 1747-9991.2010.00347.x.

Zuckerman, P. (2000a). Introduction. In P. Zuckerman (Ed.), Du Bois on Religion (pp. 1-18). Altamira Press.

Zuckerman, P. (2000b). Editorial Preface to Chapter Sixteen. In P. Zuckerman (Ed.), Du Bois on Religion (p. 143). Altamira Press.

Zuckerman, P. (2002). The sociology of religion of W.E.B. Du Bois. Sociology of Religion, 63(2), 239_ 253. https://doi.org/10.2307/3712567.

Zuckerman, P. (2004). Introduction. In P. Zuckerman (Ed.), The Social Theory of W.E.B. Du Bois (pp. 1-17). Pine Forge Press.

Publisher's Note Springer Nature remains neutral with regard to jurisdictional claims in published maps and institutional affiliations. 